\title{
DELTAIC AND SHALLOW WATER MARINE SEDIMENTATION
}

$\mathrm{T}$ HE sixth International Sedimentological Congress, held in the Netherlands and Belgium during May 29. June 2 , was attended by about 300 members from more than 20 countries. It was preceded by field trips to study the Dutch Holocene deposits, especially the tidal flat sediments of Zeeland and the coastal plain west of Amsterdam, and the lagoonal deposits of the East Flevoland polder.

The earlier sessions of the Congress were held in Amsterdam, the later ones in Antwerp. The main theme of the Congress was "Deltaic and Shallow Marine Deposits" though some papers of a general nature were also presented. After speeches of welcome by the president of the Organizing Committee, Prof. R. Tavernier, the president of the International Association of Sedimentologists, Prof. F. P. Shepard delivered his presidential address on "Criteria in Modern Sediments Useful in Recognizing Ancient Sedimentary Environments". This appropriately dealt in considerable part with the work of the spэaker and his colleagues in and around the Mississippi Delta. Prof. Shepard stressed the importance of the extensive Cænozoic tectonic activity on recent sedimentation and commented on the discovery in deep water of an increasing number of sedimentary features once regarded as indica. tive of shallow water origin.

Only about one-third of the papэrs accepted by the Congress for publication could be read and discussed at the meeting. Descriptions of recent or relatively recent deltas dealt with those of the Nigər (J. R. L. Allen) and of the Rio Grande de Santiago off west central Mexico (D. G. Moore). R. H. Dott discussed the incidence of deltaic deposition in eugeosynclinal belts, with spocial reference to the United States, and P. Wurstor described the deltaic sedimentation of the German Keupэr.

Studies of modern shallow water marine sediments included accounts of transportation and deposition along the Dutch coast (A. J. de Groot) and off Brest (A. Guilcher). H. Füchtbauer discussed the varying porosities of sediments from different environments in the southern North Sea. A papor arousing widespread interest was that in which E. J. Degens deseribed the diagenesis of organic substances off the Californian coast and reached the conclusion that the organic matter was almost entirely land derived. Modern carbonate sedimentation in the Persian Gulf was described in papers by D. J. J. Kinsman and by A. J. Wells. The patches of milky water, known as 'whitings', from which large-scale precipitation of calcium carbonate occurs were illustrated by a short film. Two other excellent films were shown in the course of the meeting, one illustrating the formation of various typos of ripples, bars and dunes in flume experiments, the other submarine erosion by slow-moving sediments.

Older shallow-water deposits described included, among others, marginal Tertiary sediments of the Paris basin (C. Pomerol) and of the sub-Alping molasss trough
(W. Zimmerle). J. P. Mangin claimed an extremely shallow-water origin for sequences interproted as 'flysch' in the Cretaceous and Eocone rocks of northern Spain. $R$. Goldring discussed the significance of the two distinct trace-fossil assemblages commonly met with in shallowwater marine sediments. A number of contributors dealt with British Carboniferous sedimentation in South Wales (G. Keeling and T. R. Owen) and in central and northern England (H. G. Reading, P. M. L. Duff and E. K. Walton). G. V. Chilingar, in a study of more than 600 core samples, showed that for sandstones of comparable grain size a close relation exists between porosity and permeability.

During the Congress a sp эcial one-day symposium on "Sedimentology and Ore Genesis" was held in Delft. The opening sossion dealt with syngenetic sulphide deposition. A. J. C. Bernard discussed the importance of adsorption and of precipitation at surface temporatures in metallogenesis. O. Schulz claimed the lead-zinc deposits of Raibl and Bleiberg as of exhalative sedimentary origin, while H. J. Schneider regarded these and other deposits in Triassic limestones and dolomites of the Eastern Alps as due to syn-sedimentary precipitation in the back reef facies. P. Nicolini drew on Moroccan examples as well as those of Mansfeld and of deposits in the Cévennes in illustration of his theories of sedimentary concentration of copper, lead and zinc. L. G. Love described, with convincing detail, the early diagenetic formation of pyrite in recent muds. G. C. Amstutz illustrated the development of four generations of diagenetic iron sulphide from Ordovician dolomitic limestones in Missouri. In collaboration with $\mathrm{P}$. Ramdohr, he quoted mineralogical evidence interpreted as indicative of pre-deformation and even preslumping deposition of much of the sulphide at Mount Isa.

A second session dealt with sedimentary iron ore deposits. J. Petránek described the evidence for shallow. water origin of the oolitic ores of the Lower Palæozoic. H. Harder drew a comparison between ores of the Minette typs to which the iron was supplied by normal weathering processes and those of the Lahn-Dill typ $ə$ in which it is believed to have come from volcanic sources. L. Bubenicek considered the conditions of deposition of the Lorraine ores stressing the importance of diagonesis. A final session dealt with the origin of phosphorites (M.Slansky), of strontiobarytes from the German Zechstein $(\mathbf{H}$. Puchelt and G. Müller) and of the Arkansas barytes deposits (R. A. Zimmermann and G. C. Amstutz). The papors and the ensuing discussion, ably summarized at the close by P. Routhier, are to be published as a separate volume from the remainder of the Congress proceedings.

After the Congress, seven different excursions in Belgium offered opportunities for studying a variety of sedimentary formations. At the goneral assembly of the International Association of Sedimentologists a proposal to hold the seventh congress in Great Britain in 1967 was unanimously approved.

\section{CONFERENCE OF THE UNIVERSITIES OF THE UNITED KINGDOM}

\footnotetext{
WHE report of procerdings of the Conference of the Universities of the Unitod Kingdom *, held in London during December 14-15, 1962, includes the text of the spөэches of Dr. E. G. Edwards and Prof. S. Wiseman in * Conference of the Universities of the United Kingdom 1962: Report of Proceedings-Alternatives to University Education; Relations Between the of the British Commonwealth, 1963.) $5 s$.
}

opening the discussion on altgrnatives to university education, and of Sir Noel Hall and Prof. A. G. Quarrel in opening the discussion on relations between the universities and industry, as well as of that of contributions to both discussions.

Dr. Edwards was concerned more espycially with the deliberate interaction of college and industry attempted 
by the colleges of advanced technology and with its implications for postgraduate study and research, education and industrial training generally, while Prof. Wiseman examined the part played by toacher training colleges as 'alternatives' to a university education. Both speakers insisted on the need to provide for some cross-over or transfer from college of technology or teacher training college to university and vice versa and on the importance of a broadly based education. Dr. P. F. R. (now Sir Percy) Venables referred to the necessity for all institutions of higher education to think in terms of university quality in determining their conditions, and in particular there should be adequate opportunities for higher study and research and professional contacts by way of travel, sabbatical leave and attendance at conferences. Prof. Wiseman's contention that the provision of teaching should be under the æegis of the universities was fully supported, but sandwich courses were not generally accepted as advantageous.

Sir Noel Hall thought that up to 1939 contacts between the university world and industry generally were much more limited in number and scope than those in other advanced countries and quite inadequate for the post-war demand, although in finance and public administration a pattern of relations had developed where practitioners welcomed discussion with university men and women on the problems of their own day-to-day responsibilities.
Much re-thinking was now taking place in industry, and probably among university appointments committees, on the placement of graduates in industry, leading to developments which were steadily improving contacts betwoen universities and industry in this respect. He thought that research by qualified univorsity people into the activities of industry itself was likely to continue to be difficult to organize and pursue, though he was not particularly concerned about the problem of secrecy. A greater difficulty was that of deciding the point in time at which important decisions had in fact been taken. This difficulty appeared to be diminishing and much activity was also being devoted to studying the tools of management.

Prof. Quarrell was concerned more with the conduct of research by universities on behalf of industry, discussing more particularly the research contract but emphasizing the value of formal opportunities for personal contacts between industrialists and members of a university through the university court, council and committess of council. In this discussion also the importance of a wider basic training for professional students was emphasized. However, the main stress was laid on the importance of personal contacts, including participation by industrialists in university government at the executive level. The desirability of avoiding the use of the term 'management' was recognized and of referring rather to 'business studies'.

\section{THE BRITISH COAL UTILIZATION RESEARCH ASSOCIATION}

$\mathrm{T}$ HE annual report for 1962 of the British Coal Utilization Research Association* includes a summary of the year's activities and lists of publications and lectures by the staff, information circulars, and membership of advisory committees and of research staff. The total staff of 310 at the end of the year comprised 63 in scientist grades, 115 in research officer and research assistant grades, 46 in clerical and administrative grades and 86 in industrial grades.

The bulk of the report is occupied by an account of research activities from which the following points are selected. A two-year programme on coal-fired boilers fitted with automatically controlled combustion equipment and ash-handling and coal-handling gear indicated that from the point of view of cost of steam generated as well as technically this assembly of coal-fired equipment can be recommended for industrial use in many localities and circumstances. Eight commercially produced solid. fuel boilers with outputs from 33,000 to 60,000 B.Th.U./h have been tested using anthracite and coal under varying conditions to provide basic information for developing more efficient and automatic appliances with high amenity. * The Fritish Coal Utilization Research Association. Annual Report,
1962. Pp. 67. (Leatherhead: The British Coal Utilization Research Association. 1963.)
Work on deposits and corrosion in large water-tube boilers has already indicated that the composition and structure of deposits are independent of time, and has led to the devising of an infra-red spectrometric method for determining sulphur trioxide and to the investigation of laboratory methods for assessing quantitatively the effects of the nature of the ash and the composition of the flue gases on the corrosion of austenitic steels.

A systematic study of the slagging properties of British coals now nearing completion should assist in the choice of coals for slagging combustion, and basic studies of combustion and gasification have sought to provide busic information on the behaviour and decomposition of coals while being heated. The apparatus for studying pre-ignition and devolatilization of small particles of coal has been further developed, enabling the amount and rate of decomposition at known particle temperatures to be determined under effectively isothermal conditions. Among instrumental advances during the year were the further improvement of the venturi pneumatic pyrometer, the use of a nuclear magnetic resonance method, a microwave method for continuous measurement of moisture in coal, and the use of ciné-photography for studying the operation of the open-screw feeder and the quenching of slag discharged from a gasifier.

\section{TRIBOPHYSICS RESEARCH IN AUSTRALIA}

$\mathrm{T}$ HE Division of Tribophysics of the Commonwealth Scientific and Industrial Research Organization of Australia is a major centre of research on the physics and chemistry of surfaces of solids and on metal physics. The annual report for $1961-62$ records that work continued on the friction and lubrication of surfaces*. Molybdenum disulphide has been shown to be superior in lubricating

* Commonwealth of Australia. Commonwealth Scientific and Industria Research Organization. Annual Report of the Division of Tribophysics for
the year ending June 30,1962 . Pp. $\mathrm{i}+19$. (Melbourne: Division of Tribophysies, C.S.I.R.O., 1962.) ability to many other inorganic compounds of comparable structure, and the effect of atmospheric humidity and water absorbed on the lubricant on burnishing and friction has been examined. Friction is highest at 100 per cent humidity. The theoretical study of how models of the atomic configurations of flat surfaces could, in principle, be constructed has now been applied to a number of different crystal structures and a set of photographs of models of about twenty of the simplest surfaces in each of the face-centred-cubic, body-centred-cubic, sodium chlor- 